\title{
Performance of growing pigs fed diets containing cassava peels meal supplemented with three levels of roxazyme G2G enzyme \\ Effiong, O. O. ${ }^{1}$ and Harry, B. J. ${ }^{2}$ \\ ${ }^{\prime}$ University of Calabar, Calabar, Cross River State. \\ ${ }^{2}$ International Institute of Agricultural Research and training, More Plantation, Ibadan \\ Corresponding author: okokoneffiong48@gmail.com \\ Phone number: 08036602048
}

\section{Abstract}

This research was designed to evaluate the performance of growing pigs fed diets containing cassava peel meal supplemented with three (3) levels of roxazyme G2 enzyme. Fresh cassava peels were gathered, thinly spread on a concrete floor to dry out and milled prior to proximate analysis and feed formulation. Five experimental diets were formulated. Diet one had maize as main energy source, while Diets 2 to 5 had $50 \%$ of maize replaced with cassava peel meal. Diets 3, 4 and 5 were further supplemented with roxazyme G2 non starch polysaccharide enzyme at $1 \mathrm{~g} / \mathrm{kg}, 1.5 \mathrm{~g} / \mathrm{kg}$ and $2 \mathrm{~g} / \mathrm{kg}$, respectively. A total of thirty (30) cross bred growing pigs were selected and distributed into five (5) groups on weight equalization basis with six (6) animals per group. Each group was assigned to one of the five (5) experimental diets in a completely randomized design. The growth and economy of production were monitored throughout the 56-day duration of the trial. At the end of the feeding trial, $10 \mathrm{mLs}$ of blood was collected from three animals on each treatment into sample bottles with EDTA for hematological analysis. Data were subjected to analysis of variance procedures. The results revealed that the three (3) levels of dietary enzyme supplementations did not significantly $(P$ 0.05) influenced the average daily feed intake but influenced the average daily weight gain and the feed conversion ratio $(F C R)$ significantly. Pigs on diets with 1.5 and $2 \mathrm{~g} / \mathrm{kg}$ enzyme supplementation had the highest average daily weight gain of $0.43 \mathrm{~kg}$ while those on $2 \mathrm{~g} / \mathrm{kg}$ enzyme supplementation diet had the best FCR with value corresponding to 1.74 . Dietary enzyme supplementation reduced $(P<0.05)$ the cost offeed production and the cost of feed consumed from $N 79.65$ and $N 3154.40$ in control diet to 43.92 and 1892.95 in $1.0 \mathrm{~g} / \mathrm{kg}$ enzyme supplementation. The cost offeed per gain was reduced from $N 172.83$ to $N 90.50$ for diet with $1.0 \mathrm{~g} / \mathrm{kg}$ enzyme supplementation. The dietary treatment had no influence on all the observed hematological parameters. It was therefore concluded that in a pig's diet where 50\% of the maize is replaced with cassava peel meal, dietary enzyme supplementation should not exceed $1.5 \mathrm{~g} / \mathrm{kg}$ of feed for optimum level of economic production.

Keywords: Cassava peel, fibre, enzyme, growing pigs

\section{Introduction}

Cereal grains (maize, sorghum, millet and wheat) constitute the bulk of livestock feeds particularly for pigs and poultry. However, in developing countries like Nigeria, demand for these cereal grains are high as they constitute staple food for human and raw materials in most confectionary industries. Consequently, there is little or no excess left for livestock feeding and when available, it is always very expensive (Adejinmi et al., 2000). For instance, in Nigeria the price of maize had increased from N45,000 per ton in 2005 to N100,000 per ton in 2018. The continuous increase in the cost of conventional energy ingredients has necessitated intensive research into the 
cheaper alternative source of energy yielding unconventional feed resources ingredients (Ben Salem et al., 2002; Amata, 2014; Olaiya and Makinde, 2015). One of such alternatives comes from the cassava tuber roots processing industry of which cassava peel is the most prominent. Cassava peel is the outer cover of the tuber roots which is usually removed manually with sharp knife, discarded and allowed to rot away, since it is always regarded as waste. With the pronouncement by Federal Government of Nigeria that flour millers should make use of not less than $20 \%$ of cassava in flour making, it implies that more cassava peels will be produced in most state of the country (Nkang and Ele, 2014). It is therefore imperative to develop technology that will increase the utilization of cassava peel in livestock ration, particularly for growing pigs. The chemical analyses revealed that cassava peel meal is high in dry matter $(82.55 \%)$, carbohydrate $(70.67 \%)$ as well as minerals (Adesehinwa, 2011). Cassava peel contains appreciable amount of protein (5.69\%), relative to $9.0 \%$ in maize (Adesehinwa et al., 2008). Adesehinwa (2008) and Adesehinwa et al. (2011), reported a high crude fibre values of $33.96 \%, 20.4 \%$ and $20.01 \%$, respectively for cassava peel which limit its utilization in monogastric nutrition. High fibre in growing pigs diets decrease the digestible and metabolizable energy concentrations and often form bulk feeds. The fibrous portion of the feed also influences the digestibility of the other constituents by exerting a protective action, encasing these constituents in a digestion proof-shed as it were, thereby obstructing the access of digestive enzymes (Yin et al., 2004; Abdullahi et al., 2011). Degradation of these complex carbohydrate compounds to simple sugars will further increase the energy value of cassava peels, hence the need for the addition of exogenous enzymes in the ration. The study was therefore designed to determine the performance of growing pigs fed cassava peel diets supplemented with three $d$ levels of roxazyme G2Genzyme.

Materials and methods

Experimental site

The study was conducted at the Piggery unit of the Teaching and Research Farm, Department of Animal Science, University of Calabar, Nigeria. The farm is located within the rain forest of south-south zone of Nigeria with a mean annual rainfall of about $1830 \mathrm{~mm}$ and average annual temperature of $24^{\circ} \mathrm{C}\left(75^{\circ} \mathrm{F}\right)$ to $30^{\circ} \mathrm{C}\left(56^{\circ} \mathrm{F}\right)$. The piggery house is an open sided, concrete floor and roofed with corrugated roofing sheet, each of the pens having separate feeding and watering arrangements.

Processing of the experimental materials Fresh cassava peels were collected from local garri processors from Calabar south local government area of Cross River State, Nigeria during dry season (November, 2016 to January, 2017), thinly spread on a concrete floor to dry out under sun for approximately five days. This was later milled in a $4 \mathrm{~mm}$ screen hammer mill at the feed mill unit of the teaching and research farm, stored prior to proximate analysis and feed formulation. Other ingredients were sourced from within and outside Calabar metropolis.

Proximate analysis

The proximate analysis of the milled cassava peel and the experimental diets were carried out according to the methods described by AOAC (2010).

Experimental diets

Five experimental diets were formulated. Diet one formed the control diet (Table 1) having maize as the main source of energy. Diets 2 to 5 had $50 \%$ of maize replaced by cassava peel meal. Diets 3, 4,5 were further supplemented with Roxazyme G2G 


\section{Effiong and Harry}

enzyme at $1 \mathrm{~g} / \mathrm{kg}, 1.5 \mathrm{~g} / \mathrm{kg}$ and $2 \mathrm{~g} / \mathrm{kg}$, respectively. The Roxazyme G2G enzyme contain complex derived from Trichodema lonibrachiatum. The main enzyme activities of these complex are cellulose (endo-1, 4- $\beta$-glucanase; EC: 3.2.1.4); $\beta$ -

Table 1: Gross composition of experimental diets

\begin{tabular}{llllll}
\hline Ingredient & $\mathbf{1 0 0 \%}$ maize & $\begin{array}{l}\mathbf{5 0 \%} \\
\mathbf{C P M}\end{array}$ & $\begin{array}{l}\mathbf{5 0 \%} \mathbf{C P M} \\
\mathbf{+ 1 . 0 g / k g} \\
\mathbf{R E}\end{array}$ & $\begin{array}{l}\mathbf{5 0 \%} \mathbf{C P M +} \\
\mathbf{1 . 5 g} / \mathbf{k g ~ R E}\end{array}$ & $\begin{array}{l}\mathbf{5 0 \%} \mathbf{C P M} \\
+\mathbf{2 . 0 g} / \mathbf{k g R E}\end{array}$ \\
\hline Maize & & & & \\
Soybean & 51.07 & 25.53 & 25.53 & 25.53 & 25.53 \\
Cassava peel meal & 15.08 & 15.08 & 15.08 & 15.08 & 15.08 \\
Wheat offal & - & 25.53 & 25.53 & 25.53 & 25.53 \\
Palm kernel cake & 17.00 & 17.00 & 17.00 & 17.00 & 17.00 \\
Bone meal & 12.00 & 12.00 & 12.00 & 12.00 & 12.00 \\
Fish meal & 3.00 & 3.00 & 3.00 & 3.00 & 3.00 \\
*Vit./min. premix & 1.00 & 1.00 & 1.00 & 1.00 & 1.00 \\
Salt & 0.25 & 0.25 & 0.25 & 0.25 & 0.25 \\
Lysine & 0.40 & 0.40 & 0.40 & 0.40 & 0.40 \\
Methionine & 0.10 & 0.10 & 0.10 & 0.10 & 0.10 \\
Total & 0.10 & 0.10 & 0.10 & 0.10 & 0.10 \\
Analysis & 100.00 & 100.00 & 100.00 & 100.00 & 100.00 \\
Crude protein (\%) & 18.00 & 17.08 & 17.08 & 17.08 & 17.08 \\
ME (Kcal/kg) & 2,804 & 2,719 & 2,720 & 2,720 & 2,720 \\
Crude fibre (\%) & 4.70 & 4.86 & 4.79 & 4.82 & 4.77 \\
\hline
\end{tabular}

* Grower mineral and premix containing the following per kg. Vitamin A, 8,0000001U; Vitamin D3, 1,6000001U; Vitamin E, 5,0001U; Vitamin KJ, 2,000mg; Thiamine, 1,500mg; Riboflavin B2 4,000mg; Pyridozine B6, 1,500mg; Anti -oxidants, 125g; Niacin, 1,500mg; Viatamin B12, 10mg; Panthotenic acids, 5,000mg; Folic acid, 500mg; Biotin, 20mg; Choline chloride 200r, manganese, 80g; Zinc, 50g; Iron, 29g; Copper, 5g; Iodine, 1.2g; Selenium, 200mg; Cobalt, 200mg.

CPM: Cassava peel meal

RE: Roxazyme G2G enzyme

\section{Experimental animals and design}

A total of thirty cross bred growing pigs (Chesterwhite X Landrace) at 12 weeks old, with the initial average weight of $14 \mathrm{~kg}$ were selected and distributed into five groups of six animals on weight equalization basis. Each group was further divided into three (3) replicates with two animals per replicate and assigned to one of the five (5) experimental diets described earlier in a complete randomized design. The pigs were allowed ad-libitum access to the diets and water, which were served in concrete troughs. The growth and economy of production were monitored throughout glucanase (endo-1, 3 (4) $\beta$-glucanase; EC: 3.2.1.6) and xylanase (endo-1, 4- $\beta$ xylanase; EC: 3.2 .1 .8 ). The enzyme is expected to attack the complex bonds in the cassava peel, breaking them into simpler carbohydrates for the animals' endogenous enzymes to act on. 
Statistical analysis

Data obtained were subjected to analysis of variance procedures. The SAS computer software package (SAS, 2008) was used for all statistical analyses.

\section{Results and discussion}

Proximate composition of cassava peel meal

Proximate composition of the cassava peel meal is as presented in Table 2. The percentage dry matter, crude protein, ether extract, crude fibre and ash with values corresponding to $81.43 \%, 4.32 \%, 11.67 \%$, $27.40 \%$ and $5.69 \%$, respectively were higher than values reported by Adesehinwa et al. (2011) but lower than those observed by Abiola-olagunju et al. (2014) except for crude protein and ash contents.

Table 2: Proximate composition of cassava peel meal (\%)

\begin{tabular}{ll} 
Constituents & Composition \\
\hline Dry matter & 81.43 \\
Crude protein & 4.32 \\
Crude fiber & 27.40 \\
Ether extract & 11.67 \\
Ash & 5.69 \\
\hline
\end{tabular}

Performance of growing pigs fed cassava peel meal diets with three (3) levels of enzyme supplementation

Performance of growing pigs fed cassava peel meal diets supplemented with three levels of enzyme supplementations are presented in Table 3. The average daily feed intake ranged from $0.71 \mathrm{~kg}$ in pigs fed control diet to $0.77 \mathrm{~kg}$ in pigs fed diet containing $1 \mathrm{~g} / \mathrm{kg}$ dietary enzyme supplement. The values were statistically similar ( $\mathrm{P}$ 0.05) across the treatment groups. The insignificant relationship among the treatment groups for average daily feed intake implied that the diets supplied sufficient energy to meet the animals' requirement, since animals eat to satisfy their energy requirement. The enzyme supplementation may have resulted in the degradation of the carbohydrate compounds to simple sugar to further increase the energy value of the cassava peel meals (Adeshinwa, 2004; Adesehinwa et al., 2011). The result obtained in this experiment was in agreement with earlier reports (Jacob et al., 2000; Nadem et al., 2005; Choe et al., 2017). These authors did not observe any difference in the average daily feed intake of poultry and pigs fed enzyme supplemented diets relative to those on respective non-enzyme supplemented diets. The average daily weight gain was lowest $(0.33 \mathrm{~kg})$ in pigs fed cassava peel meal diet without enzyme supplementation and highest $(0.41 \mathrm{~kg})$ in animals fed diet supplemented with $2 \mathrm{~g} / \mathrm{kg}$ roxazyme G2Genzyme. The result showed that pigs fed enzyme supplemented diets recorded superior $(\mathrm{P}<0.05)$ weight gain relative to those fed control diets (maize based diet and cassava peel meal diet without enzyme supplementation). Values of the average daily weight gain increased with elevated levels of enzyme in the diets. The superior weight gains among pigs fed enzyme supplemented diets relative to those fed control diet could be attributed to enhanced utilization of the fibrous diet, as a result of the roxazyme $\mathrm{G} 2 \mathrm{G}$ enzyme (Chesson, 1993). Abubakar (1997); Adeshinwa et al. (2008) reported enzyme as a source of high quality protein amino acid (lysine) and vitamins, hence its growth promoting properties. The result also indicated that enzyme supplementation above $1.5 \mathrm{~g} / \mathrm{kg}$ of feed was an economic waste as this did not result in an improvement in the rate at which the feed was utilized. The average 


\section{Effiong and Harry}

daily weight gains of pigs on $1.5 \mathrm{~kg} / \mathrm{kg}$ and $2.0 \mathrm{~kg} / \mathrm{kg}$ enzyme supplemented diets were similar to the values reported by Wang et al. (2008) for growing pigs fed diets containing rough rice with or without NSP enzymes and Adesehinwa et al. (2011) for pigs consuming cassava peel based diet supplemented with or without Farmazyme 3000 proenx. The feed conversion ratio (FCR) values differed $(\mathrm{P}<0.05)$ significantly among the treatment groups. Pigs on $1.5 \mathrm{~g} / \mathrm{kg}$ and $2 \mathrm{~g} / \mathrm{kg}$ enzyme supplemented diets had superior FCR values of 1.90 and 1.83 , respectively compared with those on maize based diet with FCR value of 2.15 and cassava peel diets without enzyme supplementation with the FCR value corresponding to 2.90 .
The FCR values obtained in this experiment were superior to those reported by Adesehinwa et al. (2008); Adesehinwa et al. (2011) and Bhuiyan et al. (2013) for pigs fed diets containing cassava peel meal with various levels of enzyme supplementation. Improved FCR values observed among pigs on the enzyme supplemented diets could have been occasioned by the role of xylanase or possibly $\beta$-glucanase in roxazyme $\mathrm{G} 2 \mathrm{G}$ to disrupt the cell wall fractions in CPM as earlier reported by Oladunjoye and Ojebiyi (2010). Additionally, xylanase supplementation had been reported to improve nutrient digestibility and energy metabolizability in broiler chickens (Ogunsipe et al., 2015).

Table 3 : Performance of growing pigs fed cassava peel meal diets with different levels enzyme

\begin{tabular}{|c|c|c|c|c|c|c|}
\hline Ingredient & $\begin{array}{l}100 \% \\
\text { Maize }\end{array}$ & $\begin{array}{l}50 \% \\
\text { CPM }\end{array}$ & $\begin{array}{l}50 \% \mathrm{CPM} \\
+ \\
1.0 \mathrm{~g} / \mathrm{kgRE}\end{array}$ & $\begin{array}{l}50 \% \mathrm{CPM}+ \\
1.5 \mathrm{~g} / \mathrm{kgRE}\end{array}$ & $\begin{array}{l}50 \% \mathrm{CPM}+ \\
2.0 \mathrm{~g} / \mathrm{kgRE}\end{array}$ & \pm SEM \\
\hline Initial weight (kg) & 14.03 & 13.73 & 14.00 & 13.90 & 13.83 & 0.15 \\
\hline Final weight $(\mathrm{kg})$ & 32.28 & 30.98 & 32.90 & 36.17 & 36.37 & 0.66 \\
\hline Total weight gain $(\mathrm{kg})$ & 18.25 & 17.25 & 18.90 & 22.25 & 22.54 & 0.72 \\
\hline Av. daily wt. gain (kg) & $0.35^{b}$ & $0.33^{\mathrm{b}}$ & $0.36^{\mathrm{b}}$ & $0.43^{\mathrm{a}}$ & $0.43^{\mathrm{a}}$ & 0.23 \\
\hline Av. daily feed intake $(\mathrm{kg})$ & 0.71 & 0.90 & 0.77 & 0.76 & 0.75 & 0.07 \\
\hline Feed conversion ratio & $2.03^{\mathrm{b}}$ & $2.72^{\mathrm{a}}$ & $2.13^{\mathrm{b}}$ & $1.79^{c}$ & $1.74^{\mathrm{c}}$ & 0.20 \\
\hline
\end{tabular}

Economics of feeding enzyme supplemented cassava peel meal based diets to growing pigs

The economics of feeding enzyme supplemented diets to growing pigs are presented in Table 3.

The cassava peel meal at $50 \%$ replacement level significantly ( $\mathrm{P}$ 0.05) reduced the cost of producing a kilogram of feed with maize as a main source of energy by $57 \%$ (that is from N79.65 to N37.43). Enzyme supplementation of diet containing $50 \%$ cassava peel at $1.0 \mathrm{~g} / \mathrm{kg}, 1.5 \mathrm{~g} / \mathrm{kg}$ and 2.0 $\mathrm{g} / \mathrm{kg}$ reduced the cost of feed production by
$44.86 \%, 40.76 \%$ and $36.69 \%$, respectively relative to maize based diet. The significant reduction in feed cost due to the inclusion cassava peel meal and enzyme suggest that pigs' farmers could still sustain their business when the price of maize is no longer affordable. The cost of feed consumed by pigs fed diets containing cassava peel and those fortified with the three levels of enzymes were lower (P 0.05) relative to those on maize based diet. The cost of feed consumed by pigs on cassava peel meal fortified with $1.5 \mathrm{~g} / \mathrm{kg}$ and $2.0 \mathrm{~g} / \mathrm{kg}$ enzymes were statically higher 
$(\mathrm{P}<0.05)$ than those on the enzyme free cassava peal meal diet. The cost of feed consumed by pigs on diet supplemented with $1.0 \mathrm{~g} / \mathrm{kg}$ was however not different $(\mathrm{P}>0.05)$ from those of enzyme free cassava peel meal diet.

Dietary enzyme supplementation significantly reduced the average cost of feed per gain from N109 in the cassava peel meal diet without enzyme to $\$ 9.25$ in the diet with $1.5 \mathrm{~g} / \mathrm{kg}$ enzyme supplementation. The levels of enzyme supplementation did not affect $(\mathrm{P}>0.05)$ the cost of feed per gain significantly. The economics of feeding enzyme supplemented diet to pigs showed a reduction in cost with enzyme inclusion in the diet. It was relatively cheaper to produce a kilogram of pork with the dietary enzyme supplementation.

Table 4: Economics of feeding enzyme supplemented cassava peel meal based diets to growing pigs

\begin{tabular}{|c|c|c|c|c|c|c|}
\hline PARAMETERS & $\begin{array}{c}100 \% \\
\text { Maize diet }\end{array}$ & $\begin{array}{l}50 \% \\
\text { CPM }\end{array}$ & $\begin{array}{c}50 \% \\
\text { CPM } \\
+1.0 \mathrm{~g} / \mathrm{kgR} \\
\mathrm{E} \\
\end{array}$ & $\begin{array}{c}50 \% \\
\text { CPM+ } \\
\text { 1.5g/kgR } \\
\text { E }\end{array}$ & $\begin{array}{c}50 \% \\
\text { CPM+ } \\
2.0 \mathrm{~g} / \mathrm{kgR} \\
\mathrm{E}\end{array}$ & 土SEM \\
\hline Cost per kg of feed (N) & $79.65^{a}$ & $37.43^{d}$ & $43.92^{c}$ & $47.18^{c}$ & $50.43^{c}$ & 1.71 \\
\hline Av. Cost of feed consumed $(\mathrm{N})$ & $3154.14^{\mathrm{c}}$ & $1880.48^{\mathrm{c}}$ & $1892.95^{\mathrm{c}}$ & $2009.87^{\mathrm{b}}$ & $2107.98^{b}$ & 9.80 \\
\hline Av. Cost of feed per gain (N) & $172.83^{\mathrm{a}}$ & $109.01^{\mathrm{b}}$ & $100.16^{\mathrm{c}}$ & $90.25^{c}$ & $93.52^{c}$ & 2.47 \\
\hline $\begin{array}{l}\text { Means with different superscript on } \\
\text { SEM: Standard error of mean } \\
\text { CPM: Cassava peel meal } \\
\text { RE: RoxazymeG2G enzyme }\end{array}$ & & icantly & ent $\left(\begin{array}{ll}P & 0.0\end{array}\right.$ & & & \\
\hline
\end{tabular}

Haematological indices of growing pigs fed cassava peel meal diets with enzyme supplementation

The haematological parameters of growing pigs observed in this study are shown in Table 4. Hematology is routinely used in veterinary medicine to evaluate the health status of animals (Mufuvadze and Erlwanger, 2007). Reduction in the concentrations of erythrocytic parameters such as PCV, RBC counts and $\mathrm{HB}$ and elevation in $\mathrm{MCV}$ are indication of macrocytic (regenerative) anemia emanating from increased destruction and subsequent enhanced erythrosis in the liver, spleen and kidneys (Jain, 1986).

The result obtained indicated that the dietary treatments had no significant (P 0.05) influence on all the observed hematological parameters. Values were within the normal range, indicating that neither the cassava peel meal nor the different enzyme levels impacted any detrimental effect on the animals.

Table 5: Haematological indices of growing pigs fed cassava pe el meal diets supplemented with

\begin{tabular}{lcccccc} 
Parameters & $\begin{array}{c}\mathbf{1 0 0 \%} \\
\text { maize }\end{array}$ & $\begin{array}{c}\mathbf{5 0 \%} \\
\text { CPM }\end{array}$ & $\begin{array}{c}\mathbf{5 0 \%} \mathbf{C P M}+ \\
\mathbf{1 . 0 g} / \mathbf{k g R E}\end{array}$ & $\begin{array}{c}\mathbf{5 0 \%} \mathbf{C P M}+ \\
\mathbf{1 . 5 g} / \mathbf{k g R E}\end{array}$ & $\begin{array}{c}\mathbf{5 0 \%} \mathbf{C P M}+ \\
\mathbf{2 . 0 g} / \mathbf{k g R E}\end{array}$ & +SEM \\
\hline PVC (\%) & 30.0 & 27.0 & 32.0 & 31.0 & 29.0 & 0.50 \\
RBC X10 12/L & 5.2 & 4.4 & 4.4 & 5.0 & 4.5 & 0.25 \\
HB (g/Di) & 10.0 & 9.0 & 10.5 & 10.2 & 9.5 & 0.33 \\
MCMC (\%) & 33.3 & 33.3 & 32.8 & 32.9 & 32.8 & 0.23 \\
MVC (FI) & 57.7 & 60.0 & 72.7 & 62.0 & 64.4 & 1.0 \\
MCH (P/gcell) & 20.0 & 24.0 & 20.0 & 20.0 & 20.0 & 0.54 \\
\hline
\end{tabular}

SEM: Standard error of mean

CPM: Cassava peel meal

RE: RoxazymeG2Genzyme 


\section{Conclusion}

It was therefore concluded that in a pig's diet where $50 \%$ of the maize is replaced with cassava peel meal, dietary enzyme supplementation should not exceed $1.5 \mathrm{~g} / \mathrm{kg}$ of feed for optimum returns on investment.

\section{References}

Abdollahi, M. R., Ravindran, V., Wester, T. J., Ravindran, G., and Thom a s, D. V. 2011 . Influence of feed form and conditioning temperature on performance, apparent metabolisable energy and ileal digestibility of starch and nitrogen in broiler starters fed whe a t based diet. Anim Feed Sci Technol. 168:88-99.

Abiola-Olagunju, O., Mako, A. A. and Akinsoyinu, A. O. 2014. Evaluation of chemical composition and nutritive potential of oil palm slurry fermented with cassava peel as feed for livestock. African Journal of Agricultural Research. 9(26):2062-2067.

Abubakar, A. 1997. Influence of yeast supplementation on the performance of starter pulletchicks fed high palm kernel meal. MSc. Thesis. Department of Animal Science, University of Ibadan, Ibadan, Nigeria.

Adesehinwa, A. O. K. 2004. Growth performance and serum metabolites of young pigs fed maize offal as energy source. $E$. Afr. J. Life Sci. 5(2): 87-96.

Adejinmi, O. O., Adejinmi, J. O. and Adeleye, I. O. A. 2000.

Replacement value of fish meal with soldier fly larvae meal in broiler diets. Nigerian Poultry
Science Journal. (1):52- 60.

Adesehinwa, A. O. K. 2008. Comparative utilization of two sources of expeller extruded soybean meal as a replacement for on-farm processed soybean in diets of growing-finishing pigs. Afr. J. Agric. Res. 3(8): 574-577.

Adesehinwa, A.O.K., Dairo, F.A.S. and Olagbegi, B.S. 2008a. Response of growing pigs to cassava peel based diets supplemented with Avizyme 1300: growth, serum and hematological indices. Bulgarian J. Agric. Sci. 14(5): 491-499.

Adesehinwa, A. O. K., Obi, O. O., Makanjuola, B. A., Oluwole, $O$. O. and Adesina, M. A. 2011. Growing pigs fed cassava a peel based diet supplemented with or without Farmazyme_ 3000 proenx: Effect on growth, carcass and blood parameters. Afri. J. Biotechnol., 10(14):2791-2796.

Amata, I. A. 2014. The use of nonconventional feed resources (NCFR) for livestock feeding in the tropics: a review. Journal of Global Biosciences. 3(2):604-613.

A. O. A. C. 2010. Official Methods of Analysis. Association of Official Analytical Chemists International (19 ${ }^{\text {th }}$ Edition), Maryland U.S.A.

Ben Salem, H., Nefzaoui, A. and BenSalem, L. 2002. Nitrogen Supplementation improves the n u tritive valu e of Opuntiaficusindica $f$. inermisbased diets and sheep growth. In: proceedings of the $4^{\text {th }}$ International Congress on Cactus Pear and Cochinea 1, Nefzaoui, A. and Inglese, P. (eds), Hammamet (Tunisia), 22-28 October 2000. ActaHorticulturae, 581: 317-321. 
Growing pigs fed diets containing cassava peels meal supplemented with three levels of roxazyme G2G enzyme

15.

Bhuiyan, M. M., Islam, A. F. and Iji, P. A. 2013. High levels of maize in broiler diets with or without $\mathrm{m}$ i c r o b i a 1 e $\mathrm{n} \mathrm{z}$ y m e supplementation. S. Afr. j. anim. sci. 43(1) 1-16.

Chesson, A. 1993. Feed enzymes. Anim. Feed Sci. Technol. 45:65-79.

Choe, J., Kim, K. S., Kim, H. B., Park, S., Kim, J., Kim, S., Kim, B., Cho, S. H., Cho, J.Y., Park, I. H., Cho, J. H. and Song, M. 2017. Effects of protease on growth performance and carcass characteristics of growing-finishing pigs. S. Afr. J. anim. sci. 47 (5):1-11

Jacob, J. P., Ibrahim, R. Blair, H. Namkung, and Paik, I. K. 2000. Using enzyme supplemented, reduced protein diets to decrease nitrogen and phosphorus excretion of broilers. Asian-Australas. $J$. Anim. Sci. 13:1561-1567.

Jain, N. C. 1986. Schalm's Veterinary Haematology, $4^{\text {th }}$ Ed. Lea and Ferbiger, Philadelphia

Kaneko, J. J. 1989. Clinical Biochemistry of Domestic Animals. Academic Press Inc. London.

Mafuvadze, B. and Erlwanger, K. H. 2007. The effect of EDTA, heparin and storage on the erythrocyte osmotic fragility, plasma osmolality and haematocrit of adult ostriches (Struthiocamelus). Vet. Arhiv. 77: 427-434.

Nadeem, M. A., Anjum, M. I., Khan, A. G. and Azim, A. 2005. Effect of dietary supplementation of nonstarch polysaccharide degrading enzymes on growth performance of broiler chicks. Pakistan Vet. J. 25(4): $1-5$.
Nkang, M. O. and Ele, I. E. 2014. Technical efficiency of cassava producers in Ikom agricultural zone of Cross River State-Nigeria. Journal of research in agriculture and animal science . 2(10): 9-15

Ogunsipe, M. H., Adejumo, J. O., Agbede, J. O. and Asaniyan, E. K. 2015. Effect of roxazyme G2G supplementation on cassava plant meal fed to broiler chickens. Livestock Research for Rural Development 27: (12) 1-7.

Oladunjoye, I. O. and Ojebiyi, O. O. 2010. Performance characteristics of broiler chickens (Gallus gallus) fed rice (Oryza sativa) bran with or without roxazyme $\mathrm{G} 2 \mathrm{G}$. International journal of animal and veterinary advances 2 (4): 135-140.

Olaiya, O. D. and Makinde, O. J. 2015. Response of broiler chickens fed diets containing differently processed sesame (sesame indicum l.) seed meal. Academic research journal of agricultural science and research. 3(2):13-20.

Wang, M. Q., Xu, J. Y. and Kim, B. G. 2008. Effects of enzyme supplementation on growth, intestinal content viscosity, and digestive enzyme activities in growing pigs fed rough rice-based diet. Asian-Aust. J. Anim. Sci. 21(2): 270 - 276.

SAS Institute Inc. 2008. SAS/STAT ® 9.2 User's Guide. Cary, NC: SAS Institute Inc.

Received: $12^{\text {th }}$ May, 2018 Accepted: 31 ${ }^{\text {st }}$ August, 2018 